\title{
Lactic acid bacteria antibacterial and immunomodulatory properties in norm and intravaginal staphylococcosis
}

\author{
Lidia P Babenko*, Viktoria V Mokrozub, Olena Yu Sokolvyak, Liudmyla M Lazarenko, Mykola Ya Spivak \\ From EPMA-World Congress 2013 \\ Brussels, Belgium. 20-21 September 2013
}

\begin{abstract}
Introduction
It is known that uncomplicated infections of urinary tract and vaginosis are often caused by opportunistic commensal bacteria of the Staphylococcus genus. The newest probiotics based on representatives of the normal commensal microflora - non-pathogenic lactic acid bacteria with antibacterial and immunomodulatory properties may become alternative treatment methods for patients with uncomplicated urinary tract infections and vaginosis.
\end{abstract}

\section{Methods}

In vivo experimental studies were performed on six-weekold female BALB/c mice. Staphylococcosis was modeled through intravaginal administration of the $S$. aureus strain 8325-4 to mice, in doses of $5 \times 10^{7}$ cells per animal. Twenty-four hours after infection, mice were given an intravaginal injection of a probiotic bacteria suspension at a dose of $1 \times 10^{6}$ cells per animal, once per day for 7 days.

\section{Results}

It was found that identified and characterized probiotic strains L. casei IMV B-7280, L. acidophilus IMV B-7279, L. delbrueckii subsp. bulgaricus IMB B-728, B. animalis VKL and B. animalis VKB in vitro had different antagonistic effect on museums and clinical strains of pathogenic and opportunistic microorganisms. L. acidophilus IMV B-7279, L. delbrueckii subsp. bulgaricus IMB B7280 and B. animalis VKB showed efficient antagonistic activity. Staphylococcus genus bacteria were sensitive to all these probiotic strains. Biocompatibility of lacto- and

\footnotetext{
* Correspondence: babenkolidiia@gmail.com

D.K. Zabolotny Institute of microbiology and virology, National Academy of Sciences of Ukraine, 154, Zabolotny str., Kyiv, D03680, Ukraine
}

bifidobacteria was shown, that indicates the possibility of different strain's compositions creation.

It was shown that intravaginal probiotic strains administration to intact or Staphylococcus infected mice resulted in a significant increase in lacto- and bifidobacteria number in the vagina under physiological norm and in cases of staphylococcal infection. This indicates that all of these probiotic strains temporarily colonized mice vagina. Antistaphylococcal activity in vivo was confirmed by the significant reduction of $S$. aureus 8325-4 colonies, which were seeded out from infected mice vagina. L. casei IMV B-7280 - B. animalis VKL - B. animalis VKB composition's antistaphylococcal action was the most effective and more active than in each of strains alone or in different compositions of two or three bacteria.

Immunomodulatory properties of studied strains in monoculture or in different compositions in cases of experimental intravaginal staphylococcosis in mice caused phagocytic cells functional activity increasing, immune cell activation and interferon- $\gamma$ and IL-12 production normalization in different periods of observation. However, decreased production of IL- 4 indicated the ability of these probiotic strains to balance the immune response towards increasing the level of Th1-type cytokines that guide cell type development of the immune response.

\section{Conclusion}

Probiotic strains of $L$. casei IMV B-7280, L. acidophilus IMV B-7279, B. animalis VKL and B. animalis VKB in monoculture or in different compositions are promising to create a highly effective probiotic with antistaphylococcal and immunomodulating activity for farm animals' treatment from infectious and inflammatory diseases of the urogenital tract, in particular, induced by staphylococci. 
Submit your next manuscript to BioMed Central and take full advantage of:

- Convenient online submission

- Thorough peer review

- No space constraints or color figure charges

- Immediate publication on acceptance

- Inclusion in PubMed, CAS, Scopus and Google Scholar

- Research which is freely available for redistribution

Submit your manuscript at www.biomedcentral.com/submit 